Cilt/Volume:11 Sayı/Issue:2 Haziran/June 2019

\title{
Ebru Sanatı Temasının Dökme Taş Teknolojisinde Uygulanabilirliğinin Araştırılması
}

\section{Investigation of the Applicability of Ebru Art in Cast Stone Technology}

\author{
Murat Gökçe \\ Amasya Üniversitesi, Mimarlık Fakültesi, Mimarlık Bölümü, 05100 Amasya, TÜRKIYYE
}

Başvuru/Received: 19/05/2019

Kabul/Accepted: $31 / 05 / 2019$

Son Versiyon/Final Version: 30/06/2019

\begin{abstract}
Öz
Türk sanatları arasında önemli bir yere sahip olan Ebru sanatının görsel teması günümüzde bir çok sektörde kullanılarak geniş bir kullanıcı kitlesine hitap etmekte ve beğenisini kazanmaktadır. Bu çalışmada Ebru sanatının görselliği, yüzey dokusu ve sınırsız renk ahenginin oluşturduğu muazzam temasının, dökme taş yüzeylerinde uygulanabilirliği araştırılmıştır. Dökme taşların üretiminde Ebru sanatının temasının yansıtılması için uygulanan yöntem yüzey boyaması şeklinde olmayıp, üretim sırasında uygulan ve geliştirilen döküm teknikleri ile gerçekleştirilmiştir. Araştırmada mermer tozu, nano kalsit, çimento, kuvars, polimerler, lif, su ve polikarboksilat esaslı katkı ile toz pigmentler kullanılmıştır. Ebrulu dökme taş üretiminde polikarboksilat esaslı akışkanlaştırıcı katkı kullanılarak kendiliğinden yerleşen kıvam da beton kalıplara dökülerek istenilen boyutta örnekler hazırlanmıştır. Yayılma kıvamının akıcı olmasına rağmen kullanılan toz malzemelerinin ( $>200$ mikron altı) miktarı $600 \mathrm{~kg} / \mathrm{m} 3$ ten fazla olduğundan ayrışma olmaksızın kalıba yerleşebilirlik sağlanmıştır. TS 10449'a göre doğal taş olarak kullanılan hakiki mermerlerin basınç dayanımı $50 \mathrm{MPa}$ ve eğilme dayanımı $6 \mathrm{MPa}$ olmalıdır. Ebrulu dökme taş ürünlerinin basınç dayanımı 64 MPa ve eğilme dayanımı 9,6 MPa olarak bulunmuştur. Bu mekanik sonuçlar neticesinde doğal mermerin kullanıldığı bütün alanlarda Ebrulu dökme taş ürünlerinin rahatlıkla kullanılabileceği saptanmıştır. Ebru sanatın görsel teması kullanılarak, sehpa ve bahçe masası üretimi gerçekleştirilebilir.
\end{abstract}

Anahtar Kelimeler

"Ebru sanatı, dökme taş, ev mobilyası"

\begin{abstract}
The visual theme of the art of Ebru, which has an important place among the Turkish arts, is appealing to a wide range of users by using it in many sectors. In this study, the visuality of the marbling art, the surface texture and the immense contact created by the unlimited color harmony and the applicability of the cast stone surfaces were investigated. The method used to reflect the theme of marbling art in the production of cast stones was not as a surface painting but was carried out by casting techniques applied during production. Marble powder, nano-calcite, cement, quartz, polymers, fiber, water and polycarboxylate based admixtures and powder pigments were used in the study. Polycarboxylate based plasticizer additive was used in the production of marbling cast stone. Although the flowing consistency is more than $600 \mathrm{~kg} / \mathrm{m} 3$, the powder materials used (> $200 \mathrm{microns}$ below) have been applied to the mold without decomposition. According to TS 10449, genuine marble used as natural stone should have a compressive strength of $50 \mathrm{MPa}$ and a bending strength of $6 \mathrm{MPa}$. The compressive strength of Ebru cast stone products was $64 \mathrm{MPa}$ and its flexural strength was 9.6 MPa. As a result of these mechanical results, it has been determined that Ebru cast stone products can be used in all areas where natural marble is used. Kitchen counter, coffee table and garden table can be produced by using the visual theme of marbling art.
\end{abstract}

Key Words

"Ebru art, cast stone, home furniture" 


\section{Giriş}

İnsanlarda ki görsel algılamayı etkileyen en önemli faktörlerden biride renktir. Estetik amaçlara hizmet eden, mekânın niteliğini belirleyen ve algılama sisteminin bir parçası olan renk, mekâna ayrı bir derinlik ve boyut katmaktadır. Farklı renk türlerinin insanlar üzerinde değişik psikolojik ve görsel etkileri olmaktadır. Çünkü oluşturulan renk düzenleri, kullanıcılar ve de mekânların kullanımı üzerinde doğrudan etkili olmaktadır. İster canlı, ister cansız elemanlar yönünden olsun, renk insanı en çok etkileyen tasarım elemanıdır [Kıran A. (1986)].

Kâğıt süsleme sanatlarımızdan biri olan Ebru, kitre veya benzeri maddeler kullanılarak yoğunluğu arttırılan su üzerine serpilen boyaların şekillenmesi ile oluşturulmuş olup ve bu desenlerin kâğıda aktarıldığg bir sanat dalıdır. [Arıtan A.S., (1999)].

Ebru sözcüğünün aslı Farsç’dan gelmekte olup, renklerin kâğıt üzerinde bulut kümeleri halindeki görünümünden dolayı Farsça bulut-bulutumsu anlamındaki “ebr" adını almıştır. Bu sözcük zamanla değişikliğe uğrayarak "ebri” daha sonra "ebru” halini almıştır [Sungur N, (1994)].

Ebru kelimesinin asıl olarak Ab-ru'dan geldiğini, bunun Farsça'da isim tamlaması karşılığının "yüz suyu", sıfat tamlaması karşılığının “su yüzü” demek olduğunu, çünkü bu sanatın su yüzünde icra edildiğini savunanlar da vardır [Arıtan, A, S, (2002)].

Ebru sanatı, yaşanan hayatın içindeki her şey gibi değişim ve gelişime ayak uydurmuş, günlük yaşamın içerisinde kendine haklı bir yer edinmiştir. Çağımızın sanat akımları içerisinde yeni bir boyut kazanan Ebru, günümüzde kâğıt dışındaki yüzeylere de uygulanmaktadır. Ebrunun uygulandığı yüzeyler; kitap ve defter kapları olarak, cam üzerinde, duvar kâğıtlarında, ahşap üzerinde, seramik ve çini üzerinde, fular ve eşarplarda, çeşitli kumaşlar üzerinde, deri üzerine, kravatlarda ve perdelerdedir. [Argun , (1984)].

Yeni nesil olarak adlandırılan polikarboksilat esaslı katkılar kıvam kaybını önlemek, işlenebilirliği artırmak ve betondaki vibrasyon sorununu çözmek için ilk olarak 1980'li yılların sonlarına doğru Japonya'da ortaya çıkmıştır. Polikarboksilat esaslı katkılar kullanılarak üretilen kendiliğinden yerleşen beton kendi ağırlığı ile istenilen kesite homojen bir şekilde yayılabilen, vibrasyonsuz kesitte tam doluluğun sağlanabildiği ve yüksek dayanım gibi özellikleri ile de yüksek performanslı bir betondur [Felekoğlu $v d$. 2003)].

KYB’nin kendi ağırlığı ile döküldüğü kalıba yerleşebilen ve vibrasyon gerektirmeksizin kendiliğinden sıkışabilen özel bir beton türüdür. KYB'nin en önemli avantajı sık donatılı ve dar kesitli yapı elemanlarında, boşluksuz, ayrışma ve terleme gibi problemler yaratmadan homojenliğini ve kohezyonunu koruyabilen, yüksek işlenebilirliğe sahip bir yapı malzemesi olmasıdır [Baradan, \& Felekoğlu .(2004)].

KYB'nin sağladığı faydaları özetlemek gerekirse; vibrasyonsuz ve gürültüsüz üretim, servis ömrü uzun beton elemanları, estetik görünümlü beton elemanlarının üretilebilmesi ve kalıp yüzeyinde ve betonun bünyesinde en az boşluksuz üretim olarak sıralanır.

Ebrulu dökme taş ürünlerinin üretiminde polikarboksilat esaslı kimyasal akışkanlaştırıcı katkı kullanılarak kendiliğinden yerleşen kıvam oluşturulup, hazırlanan kalıpta ki her türlü doku ve detaylar kolayca elde edilmiştir.

Dökme taş teknolojisinin kullanımı çok eski zamanlara kadar uzanmaktadır. Bazı toplulukların göçtükleri yörelerde toplama taşların bulunmaması yapay taş üretimini zorunlu kılmış ve ilk yapay taş olan kerpiç icat edilmiştir [Akman, (2003)].

Özel olarak tasarlanmış köşe taşları, duvar köşelerinde blok taş görünümü vereceğinden, düz yüzeylerde yakalanan doğallık ve estetik köşelerde de sürdürebilecektir. Kalınlıkları fazla olmadığı için uygulama yapılan mekânlarda gereksiz yer kayıplarıyla karşılaşılmaz. Duvarlara yapışan kısmı düz olduğu için tüm uygulamada düzenli ve estetik bir görünüm, fazladan herhangi bir işlem yapmadan sağlanır. [T.C. Millî Eğitim Bakanlığı, İnşaat Teknolojisi, Duvara Doğal ve Yapay Taş Kaplama, Erişim: http://megep.meb.gov.tr/, Ankara, (2012)].

Günümüzde dökme taş teknolojisi ile üretilen yapay taşların doku, dayanıklılık, işlevselik ve renkleri doğal taşlar ile kıyaslandığında ayırt edilemez seviyeye gelmiştir. Yapay taşların sınırsız renk seçeneği ile birlikte arzulanan doku ve şekillerin kalıp yüzeyine yansıtılarak kolayca elde edilmesi ile birçok projede öncelikli tercihlerden birisi olmuştur. Günümüzde tasarımcılar taş ile diğer yapı malzemelerinin ortak kullanılanımı ile oluşturulan estetik görünüme daha çok yer vermektedirler. Özellikle taş dokularının diğer yapı malzemeleri ile uyumu ve görsel kaliteyi artırmasından dolayı dökme taş teknolojisi ile üretilen yapay taşlara talep hızla artmaktadır.

Doğal olarak çeşitli doku ve renkteki taşları bir arada bulmak oldukça zordur fakat dökme taş teknolojisi le üretilen taşlar ile birçok farklı renk ve dokuyu dökme taş yüzeyinde kolayca elde etmek mümkündür. Doğal taşın sahip olmadığı doku ve renkler dökme taşlarda hayat bulmaktadır. Günümüz teknolojisi ile üretilen dökme taş ürünleri, doğal taş kaplamanın verdiği estetik, doku ve işlevselliği yansıtabilmekte hatta yüksek dayanım ve mekanik özellikleri ile doğal taşların önüne geçebilmektedir. 
Doğal taşların mevcut yoğunluğundan dolayı oluşturduğu ağır yük, dökme taşların hafif birim hacim ağırlıkta üretilebilme seçeneğini ile çözülmüştür. Dökme taşların birim hacim ağırlıkları, hafif agrega veya çeşitli kimyasal katkılar (hava sürükleyici veya köpük yapıcı katkılar) kullanılarak azaltılabilmektedir. Hafif agregaların yapısında bulunan kapalı hücre boşluklar sayesinde ayrıca yalıtım özelliği de kazandırılmıştır. Dökme taşların üretiminde kullanılan çeşitli lif ve polimerlerle güçlendirildiğinde, eğilme ve kırılma mukavemetide artırılmış olup iç ve dış mekânlarda rahatlıkla kullanılabilmektedir.

Ülkemizin ekonomik kalkınma hedeflerinde doğal taş ve dökme taş ürünleri diğer ülkelerle rekabet açısından ciddi bir sektör konumundadır. Doğal taş olarak zengin maden ocaklarına sahip olan ülkemiz, dökme taş teknolojisinin gelişmesi neticesinde bu alanda da rekabet gücü artarak devam etmektedir. Dökme taş teknolojisinin gelişimi ile üretilen taşlar ekonomik, dayanıklı, işlevsel ve estetik olarak istenen şekilde üretilebilmekte ve her geçen gün yeni kullanım alanları bulmaktadır.

$\mathrm{Bu}$ çalışma ile dökme taş teknolojisi ile üretilen taşların yüzey dokusuna Ebru sanatının görsel teması yansıtılarak yeni kullanım alanları oluşması sağlanacaktır.

\section{Materyal}

$\mathrm{Bu}$ çalışmada çimento, mermer tozu, nano kalsit, kuvars, sıvı polimer, polikarboksilat esaslı akışkanlaştırıcı katkı, polipropilen lif ve su karışımı kullanılarak Ebrulu dökme taş ürünlerinin üretimi gerçekleştirilmiştir. Bu amaçla çeşitli şekil ve boyutlarda hazırlanan kalıplara Ebrulu dökme taş ürünlerinin dökümü yapılarak şekillendirilmiştir. Çalışmada kullanılan malzemelerin fiziksel ve kimyasal özellikleri aşağıda verilmiştir.

\subsection{Mermer Tozu ve Özellikleri}

0-2 mm tane aralığında ki mermer tozu kullanılmıştır. Mermer tozunun yoğunluğu $2,7 \mathrm{gr} / \mathrm{cm}^{3}$ tür. Mermer tozunun kimyasal özellikleri Tablo 1' de verilmiştir.

Tablo 1.Mermer tozunun kimyasal özellikleri

\begin{tabular}{llllllllll}
\hline $\mathbf{K K}$ & $\mathrm{SiO}_{2}$ & $\mathrm{Al}_{\mathbf{2}} \mathbf{O}_{\mathbf{3}}$ & $\mathrm{Fe}_{2} \mathbf{O}_{\mathbf{3}}$ & $\mathbf{C a O}$ & $\mathbf{M g O}$ & $\mathbf{S O}_{3}$ & $\mathbf{N a}_{2} \mathbf{O}$ & $\mathbf{K}_{2} \mathbf{O}$ & Toplam \\
\hline 43,34 & 0,01 & 0,07 & 0,05 & 53,94 & 1,93 & 0,01 & 0,06 & 0,13 & 99,53 \\
\hline
\end{tabular}

Tablo 1' de mermer tozunun kimyasal özelliklerine göre \% 91 kalsit ve \% 9 dolomit bulunduğu tespit edilmiştir.

\subsection{Kalsit ve Özellikleri}

En büyük tane çap1 5 mikron olan kalsit kullanılmıştır. Kalsitin yoğunluğu $2.72 \mathrm{gr} / \mathrm{cm}^{3}$ ve sertliği mohs skalasına göre 3' tür.

\section{3. Çimento ve Özellikleri}

Çalışmada CEM I 52,5 tip beyaz çimento kullanılmıştır. Ebrulu dökme taş ürünlerinde çeşitli renklerin oluşturulması amacıyla

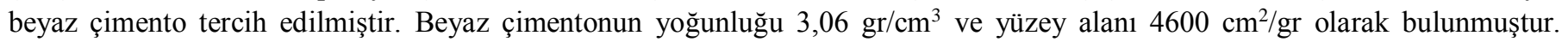
Beyaz çimentonun kimyasal özellikleri aşağıda ki Tablo 2' de verilmiştir.

Tablo 2. Beyaz çimentonun kimyasal özellikleri

\begin{tabular}{lcccccccc}
\hline $\begin{array}{l}\text { Kimyasal } \\
\text { ozellikler }\end{array}$ & $\mathrm{SiO}_{2}$ & $\mathrm{Al}_{2} \mathrm{O}_{3}$ & $\mathrm{Fe}_{2} \mathrm{O}_{3}$ & $\mathrm{CaO}$ & $\mathrm{MgO}$ & $\mathrm{Na}_{2} \mathrm{O}$ & $\mathrm{K}_{2} \mathrm{O}$ & $\mathrm{SO}_{3}$ \\
\hline$\%)$ & 21.16 & 4.05 & 0.26 & 65.7 & 1.30 & 0.30 & 0.35 & 3.30 \\
\hline
\end{tabular}

\subsection{Kuvars ve Özellikleri}

Çalışmada 2-4 mm tane çapı aralıklarında olan kuvars agregası kullanılmıştır. Kuvars agregasının fiziksel özellikleri Tablo 3' de verilmiştir.

Tablo 3. Kuvars agregasının fiziksel özellikleri

\begin{tabular}{cccc}
\hline $\begin{array}{c}\text { Tane Boyu } \\
(\mathrm{mm})\end{array}$ & $\begin{array}{c}\text { Yoğunluk } \\
\left(\mathrm{gr} / \mathrm{cm}^{3}\right)\end{array}$ & $\begin{array}{c}\text { Su emme } \\
(\%)\end{array}$ & $\begin{array}{c}\text { Sertlik } \\
(\text { Mohs })\end{array}$ \\
\hline $2-4$ & 2,67 & 0,1 & 7 \\
\hline
\end{tabular}

\subsection{Kimyasal Katkı ve Özellikleri}

Ebrulu dökme taş üretiminde polikarboksilat esaslı süper akışkanlaştırıcı kimyasal katkı kullanılmıştır. Kimyasal katkının fiziksel özellikleri Tablo 4' de verilmiştir. 
Tablo 4. Polikarboksilat esaslı akışkanlaştıııcı kimyasal katkının özellikleri

\begin{tabular}{cccc}
\hline $\begin{array}{c}\text { Yoğunluk } \\
(\mathrm{kg} / l)\end{array}$ & $\begin{array}{c}\mathbf{p H} \\
\text { değeri }\end{array}$ & $\begin{array}{c}\text { Klor içeriği } \\
(\%)\end{array}$ & $\begin{array}{c}\text { Alkali içeriği } \\
(\%)\end{array}$ \\
\hline 1,18 & 7 & 0,02 & 1 \\
\hline
\end{tabular}

\subsubsection{Akışkanlaştırııı kimyasal katkıların çalışma mekanizması}

Akışkanlaştıııı kimyasal katkılar, betonun işlenebilmesi ve uygulanabilmesi için gerekli su ihtiyacını azaltıp belirli bir süre kıvamını korumasını sağlarlar. Bu katkıların dağılma mekanizması çimento tanecikleri arasında iki farklı tip itme kuvvetine bağlıdır. Bunlar elektrostatik ve sterik itme etkileridir. Elektrostatik itme karboksil grupların verdiği negatif yükün varlığına, sterik itme etkisi ise uzun kenarlı polimerlere bağlı olarak oluşur.

\subsubsection{Dăgllma Etkisi-Elektrostatik etki}

Katkı molekülleri çimento tanecikleri tarafindan çekilerek karıştırma sırasında çimentonun yüzeyine sarılırlar. Çimento partiküllerinin katkı molekülleri tarafindan sarılması neticesinde yüzeyindeki negatif yük miktarı artar ve bu da elektrostatik itmeye Şekil 1'de neden olur. Çimento taneciklerinin yüzeyindeki negatif yükten dolayı birbirlerini iterek homojen bir dağllım oluşmasını sağlar. Bunun neticesinde betonun üretiminde kullanılan su miktarı azalmasına rağmen, betonun çalışabilirliğinin önemli ölçüde artışına yol açar [Yılmaz, (2003)].

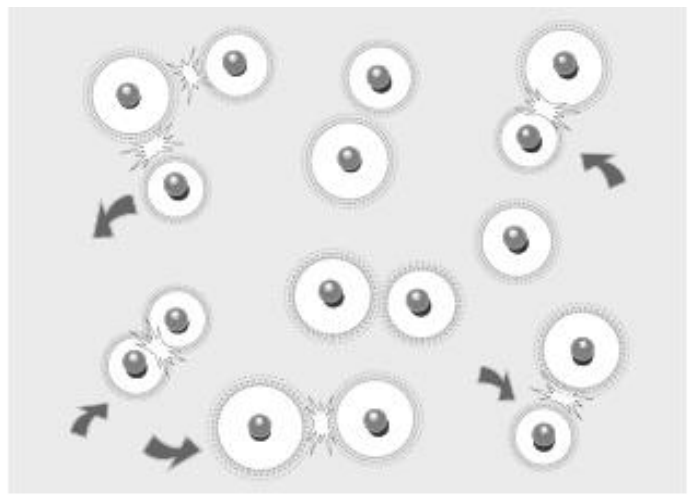

Şekil 1.Dağılma etkisi-Elektrostatik etki(Dispersion Effect-Electrostatic effect)

\subsubsection{Sterik etki}

Polikarboksilat esaslı katkı moleküllerinin sahip olduğu uzun kenarlı zincirler neticesinde sterik bir engel oluşur. Katkı moleküllerinin yarattığı bu sterik engel çimento taneciklerinin birbirine olan uzaklı̆̆ını koruyarak karışım içerisinde çok iyi bir dağılım etkisini Şekil 2'de mümkün kılar [Yılmaz, (2003)].

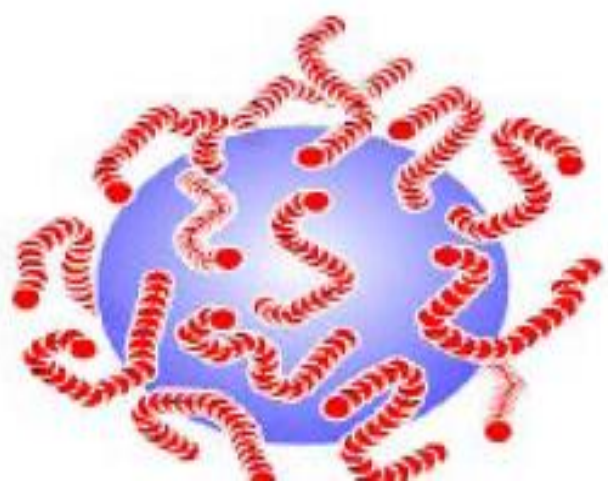

Şekil 2.Dağılma etkisi-Sterik etki-(Dispersion Effect-Steric effect)

\subsection{Polipropilen Lif}

Ebrulu dökme taş ürünlerinin sünekliğini ve eğilme dayanımını artırmak için polipropilen lif kullanılmıştır. Çalışmada kullanılan polipropilen liflerin boyu $6 \mathrm{~mm}$ ve $12 \mathrm{~mm}$, çap 50 mikrondur. Polipropilen liflere ait mekanik ve fizksel özellikler Tablo 5' de gösterilmiştir. 
Tablo 5.Polipropilen liflere ait fiziksel ve mekanik özellikler

\begin{tabular}{cccccc}
\hline $\begin{array}{c}\text { Boyut } \\
(\mathrm{mm})\end{array}$ & $\begin{array}{c}\text { Özgül ă̆ırık } \\
\left(\mathrm{gr} / \mathrm{cm}^{3}\right)\end{array}$ & $\begin{array}{c}\text { Çekme Dayanımı } \\
(\mathrm{MPa})\end{array}$ & $\begin{array}{c}\text { Erime Noktası } \\
\left({ }^{\circ} \mathrm{C}\right)\end{array}$ & $\begin{array}{c}\text { Yanma Noktası } \\
\left({ }^{\circ} \mathrm{C}\right)\end{array}$ & $\begin{array}{c}\text { Asit } \\
\text { Direnci }\end{array}$ \\
\hline 6 & 0,92 & 630 & 160 & 550 & Yüksek \\
\hline 12 & 0,92 & 630 & 160 & 550 & Yüksek \\
\hline
\end{tabular}

\section{Metod}

Ebrulu dökme taş üretiminde; mermer tozu, nano kalsit, çimento, sıvı polimer, kuvars, polikarboksilat esaslı katkı ve polipropilen lif kullanılmıştır. Ebrulu dökme taş ürünlerin de kullanılan mermer tozunun XRD analizi, taze haldeki bulamaçın yayılma kıvamı, birim hacim ağıllı̆̆ı, sertleşmiş ürünlerde basınç ve eğilme dayanım sonuçları bulunmuştur. Sertleşmiş ürünlerin yüzeyine cilalama işlemi uygulanmıştır.

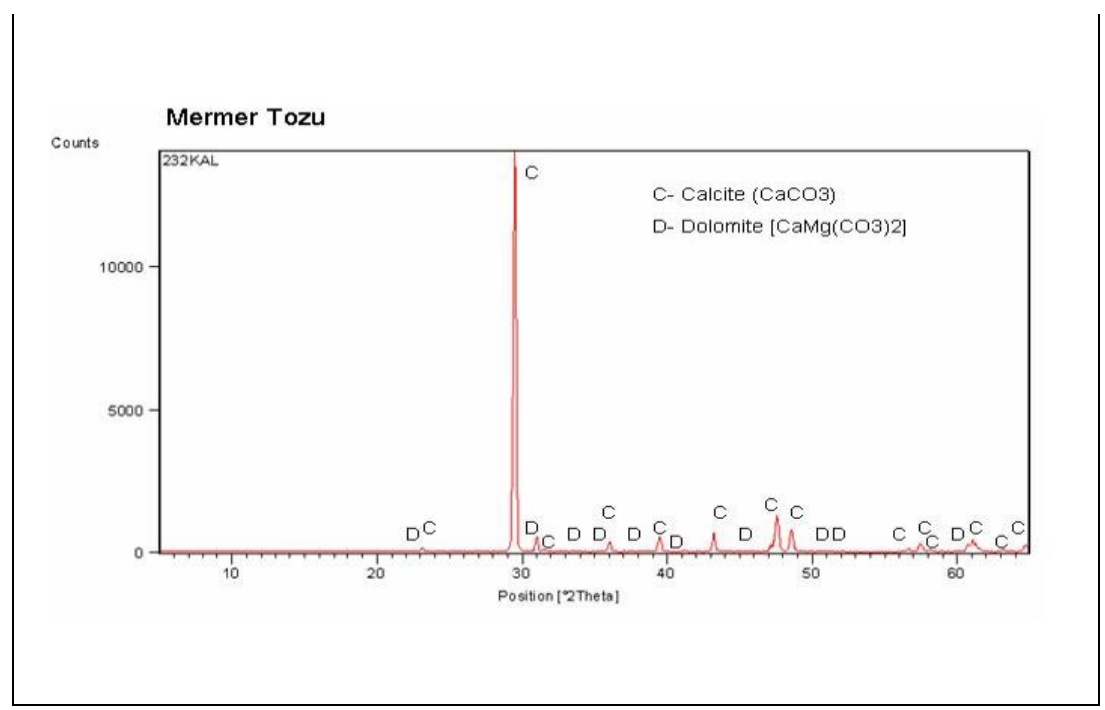

Şekil 3. Mermer tozunun XRD difraktogramı (XRD diffractogram of marble powder)

Şekil 3' de mermer tozunun XRD analizi sonucu görülmektedir. XRD grafiğine göre yüksek miktar da kalsit olduğu saptanmıştır. Ebrulu dökme taş ürünlerin hazırlanması için ilk etapta kullanılan malzemeler bulamaç (çimento, nanokalsit, sıvı polimerler,su ve polikarboksilat esaslı akışkanlaştıııı karışımı) olarak hazırlanmıştır. Ebrulu dökme taş ürünlerinin üretimi için hazırlanan bulamaçlar yüksek tork ve devir gücüne sahip, planet tipi bir karıştırıcı içerisinde 90 saniye karıştırılmıştır. Bu tip beton karıştırıcılar ile bulamaçlar çok etkin ve homojen bir şekilde karışım sağlanmıştır. Daha sonar kuvars, mermer tozu ve lifler ilave edilerek toplam 3 dakika karıştırılmıştır. Kendiliğinden yerleşen kıvam elde edildikten sonar renkli toz pigmentler ilave edilerek Ebrulu dökme taş ürünlerinin renklendirilmesi yapılmıştır.Ebru sanatının görsel temasını dökme taşların yüzeyine uygulamak için Ebru sanatında olduğu gibi el döküm teknikleri geliştirilerek uygulanmıştır.Bu teknik sayesinde ürünlerin yüzeyin de renklerin ahenkle uyumu ve her kullanıcının göz zevkine ve algılamasına hitap edecek görselliklerin oluşturulması sağlanmıştır.

Taze haldeki bulamaçlar ahşap veya polyesterden üretilen kalıplara dökülerek sertleşmesi için beklenmiştir. Sertleşen ürünlerin yüzeyine su iticilik özelliği kazandırılması için cilalama işlemi yapılmıştır. Epoksi esaslı cila kullanılarak yapılan cilalama işlemi neticesinde yüzeyde hiçbir iz bırakmadan su iticilik kazandırılmış olup ürünlerin su emme özelliği tamamen ortadan kaldırılmıştır.

Hazırlanan Ebrulu dökme taş ürünlerinin taze halde kıvamı (yayılma), birim hacim ağırlığı, sertleşmiş Ebrulu dökme taş ürünlerinin 28 günlük basınç ve eğilme dayanımı sonuçları bulunmuştur. 
Tablo 6. Ebrulu dökme taş karışım oranları

\begin{tabular}{ll}
\hline Malzemeler & $\left(\mathrm{kg} / \mathrm{m}^{3}\right)$ \\
\hline Çimento & 450 \\
Kuvars & 900 \\
Mermer Tozu (0-2 mm) & 650 \\
Kalsit & 160 \\
Polimer & 25 \\
Polipropilen Lif (6 mm) & 4 \\
Polipropilen Lif (12 mm) & 3 \\
Akışkanlaştırıcı & 5 \\
Toz Pigment & 1 \\
Su & 168 \\
\hline
\end{tabular}

Tablo 6' da Ebrulu dökme taş üretiminde kullanılan malzemelerin karışım oranları verilmiştir. Polikarboksilat esaslı katkılar kullanılarak yapılan Ebrulu dökme taş ürünlerinin üretiminde kullanılan malzemeler için karışım oranları, ayrışma oluşmaması için ince malzeme (100 mikron elek altında kalan malzeme) miktarı toplamı en az $650 \mathrm{~kg} / \mathrm{m}^{3}$ olarak hesaplanmıştır. Taze halde kendiliğinden yerleşen kıvamda dökülerek, hazırlanan kalıpta ki bütün yüzey detayların alınması mümkün olmuştur.

Tablo 7. Taze ve sertleşmiş Ebrulu dökme taş ürünlerinin özellikleri

\begin{tabular}{ccccc}
\hline \multicolumn{2}{c}{ Taze haldeki Özellikler } & \multicolumn{3}{c}{ Sertleşmiş Ebrulu dökme taş'nin Özellikleri } \\
\hline Kıvam & Birim hacim & Basıç̧ & Ĕ̆ilme & Su emme \\
Yayılma & ağırlık & dayanımı & Dayanımı & \\
$(\mathrm{cm})$ & $\left(\mathrm{kg} / \mathrm{m}^{3}\right)$ & $(\mathrm{MPa})$ & $(\mathrm{MPa})$ & $(\%)$ \\
\hline 66 & 2345 & 64 & 9,6 & 0 \\
\hline
\end{tabular}

Ebrulu dökme taş ürünlerinin eğilme dayanım tayini TS EN 12390-05'e göre ve basınç dayanımı tayini TS EN 12390-4' e göre yapılmıştır. Tablo7'de eğilme ve basınç dayanım sonuçları verilmiştir. TS 10449'a göre doğal taş olarak kullanılan hakiki mermerlerin basınç dayanımı $50 \mathrm{MPa}$ ve eğilme dayanımı $6 \mathrm{MPa}$ olmalıdır. Ebrulu dökme taş ürünlerinin basınç dayanımı 64 $\mathrm{MPa}$ ve eğilme dayanımı 9,6 MPa olarak bulunmuştur. Ebrulu dökme taş ürününün basınç ve eğilme dayanımları doğal taş mermerden daha yüksek olduğu ve mermerlerin kullanıldığı alanlarda kullanılabileceği tespit edilmiştir.

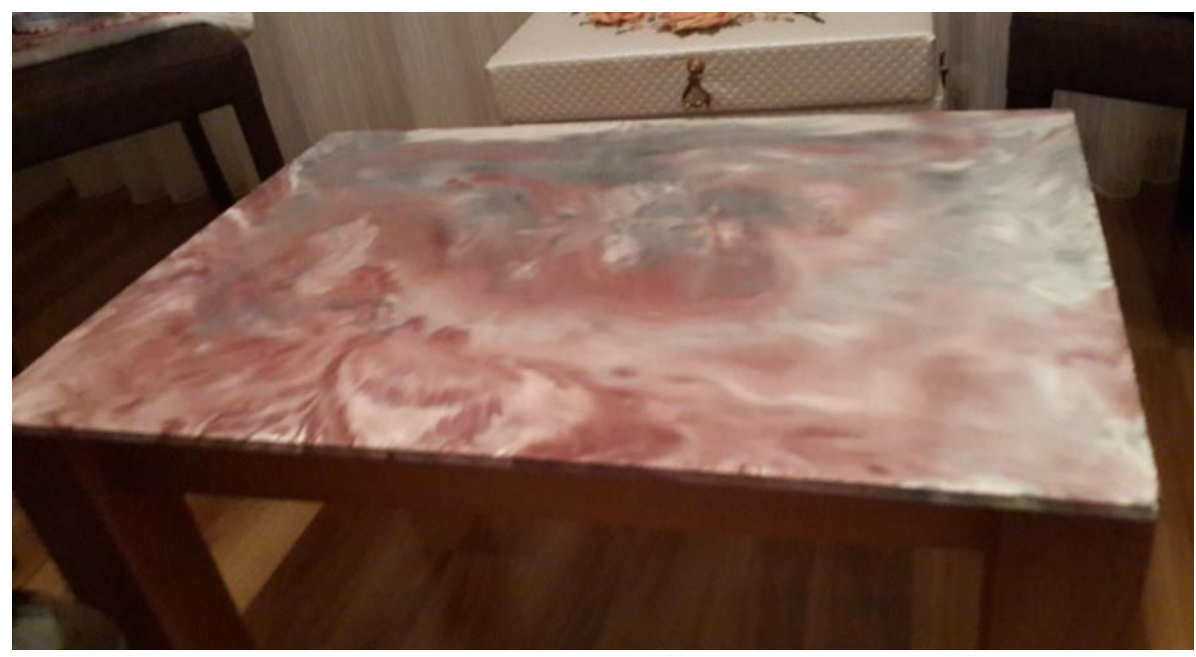

Şekil 4. Sehpa tasarımında kullanılan Ebrulu dökme taş örneği 
Şekil 4' de bordo, siyah ve kırmızı pigmentler kullanılarak renklerin ahenkle buluşmasının sağlandığı ev mobilyası olarak kullanılan sehpa üstü dökme taşı görülmektedir. Sehpanın ayakları ahşaptan yapılmış olup, ahşap ve dökme taşın bütünleşmesi sağlanmıştır. Sehpanın boyutları 50x70 cm ve kalınlığı 16 mm’ dir. Yüzeyine uygulanan cilalama neticesinde Ebrulu dökme taş ürünlerinin yüzeyinde leke ve kir tutması önlenmiş ve gerektiğinde yüzey temizliğinin kolay olmasını mümkün kılmıştır.

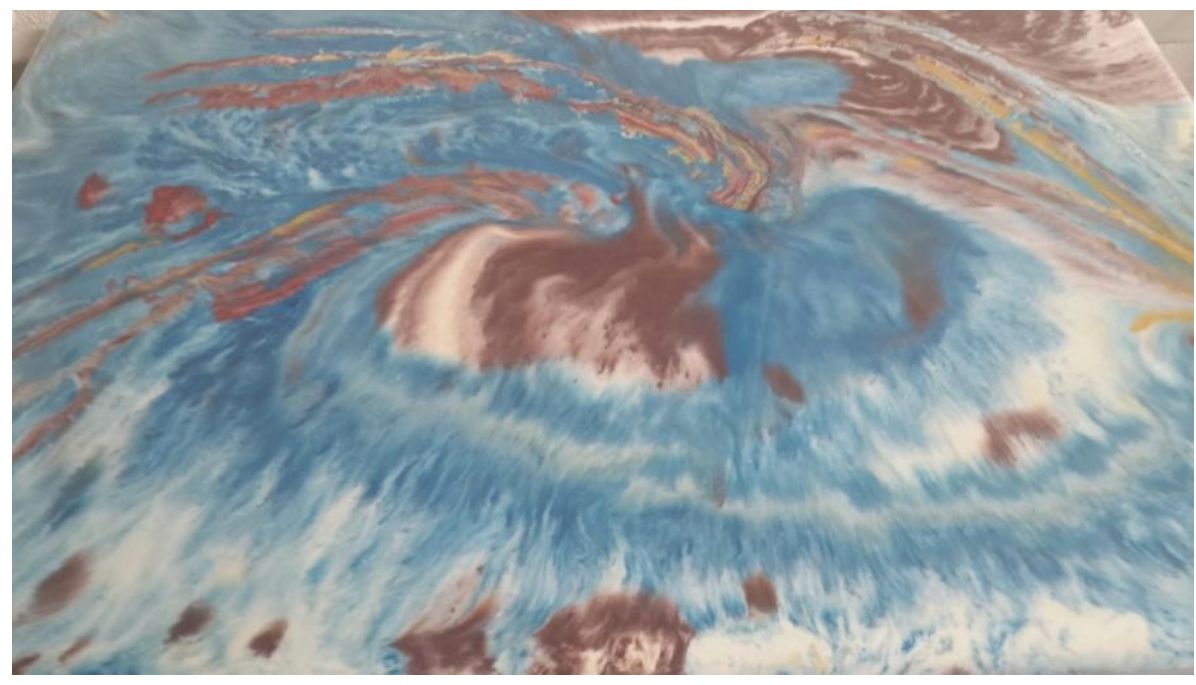

Şekil 5. Farklı renk tonlarında üretilmiş Ebrulu dökme taş örneği

Şekil 5' te Ebrulu dökme taş ile üretilen yapay taşların doku ve renklerinin doğal taşlardan ayırt edilemez seviyeye geldiği görülmektedir. Doğal taşlarda bulunması zor olan renk ve dokular, dökme taşlarda sağlanarak kullanıcısına sınırsız renk seçeneği sunmaktadır. Ayrıca polimer ve liflerle güçlendirilerek doğal taşlarda yaşanan kırılma ve çatlama sorunlarının da önüne geçilmiştir.

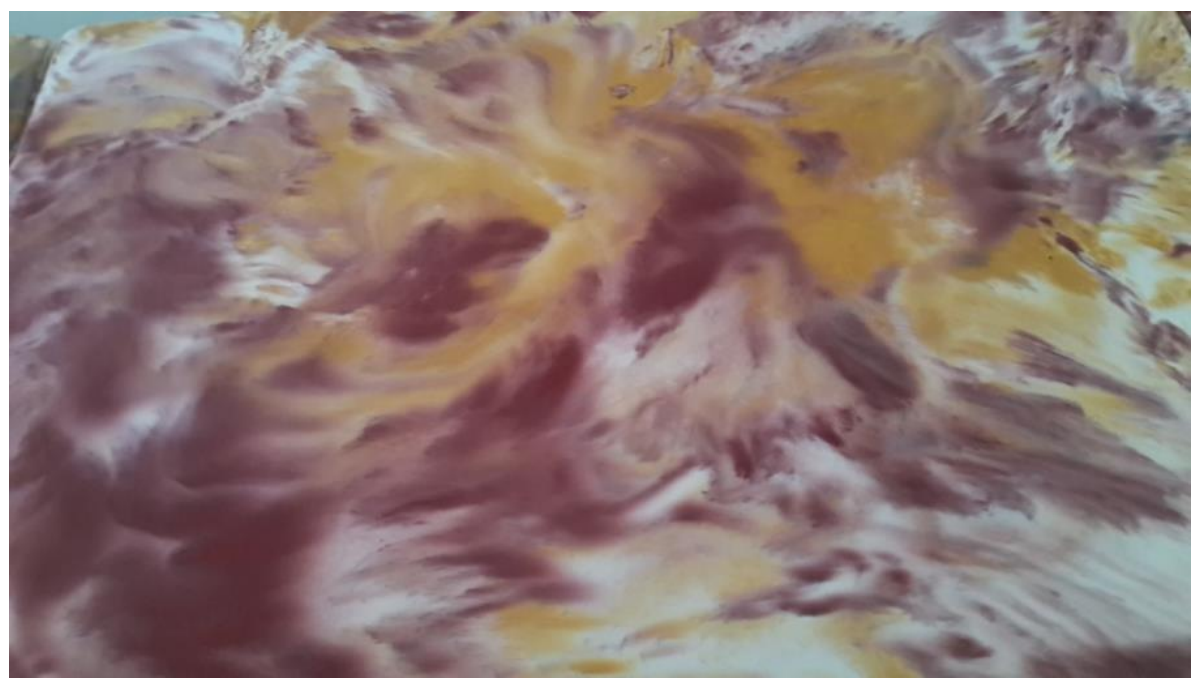

Şekil 6. Sarı ve bordo pigmentlerle üretilmiş Ebrulu dökme taş örneği

Şekil 6' da sarı ve bordo Şekil 7' de ise sarı ve kahverengi pigmentlerle renklendirilmiş Ebrulu dökme taş örnekleri görülmektedir. $\mathrm{Bu}$ ürünlerin yüksek çekme ve eğilme dayanımı neticesinde yer ve duvar döşemesi olarak da kullanılmasını mümkün kılmaktadır. Beyaz tonlar için beyaz çimentonun kendi renk tonundan yararlanılmıştır. Kuvars agregalarının kullanımı ile aşınmaya karşı direncide artırılmıştır. 


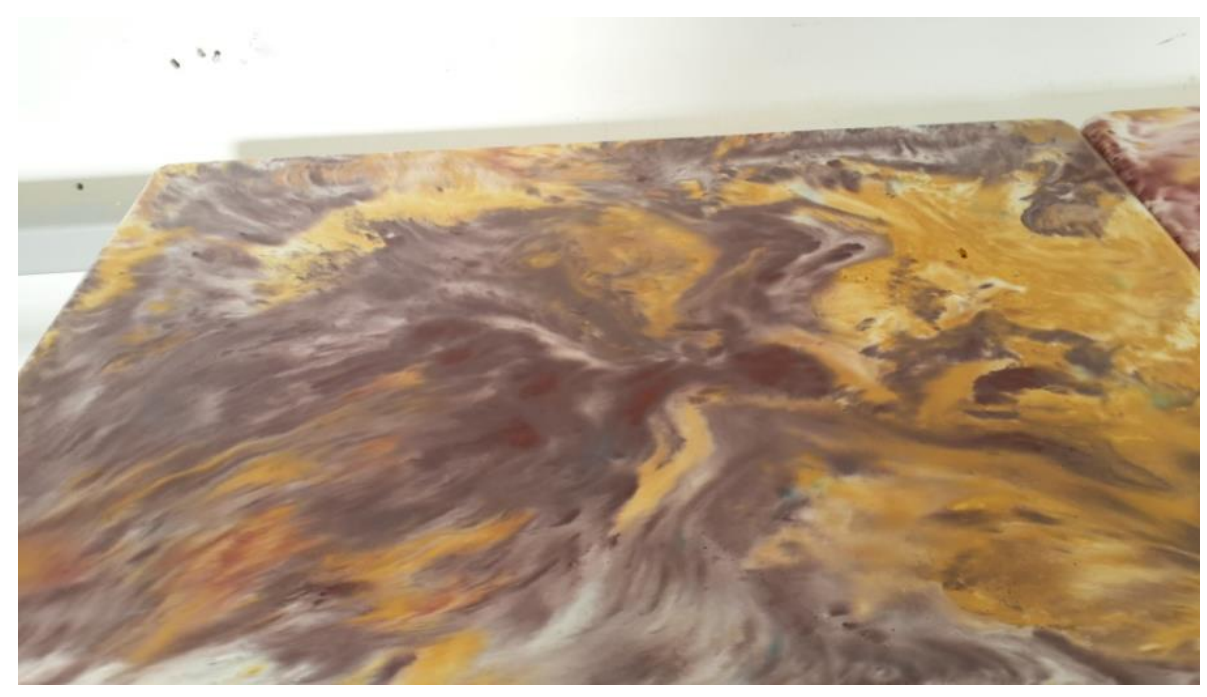

Şekil 7. Sarı ve kahverengi pigmentlerle üretilmiş Ebrulu dökme taş örneği

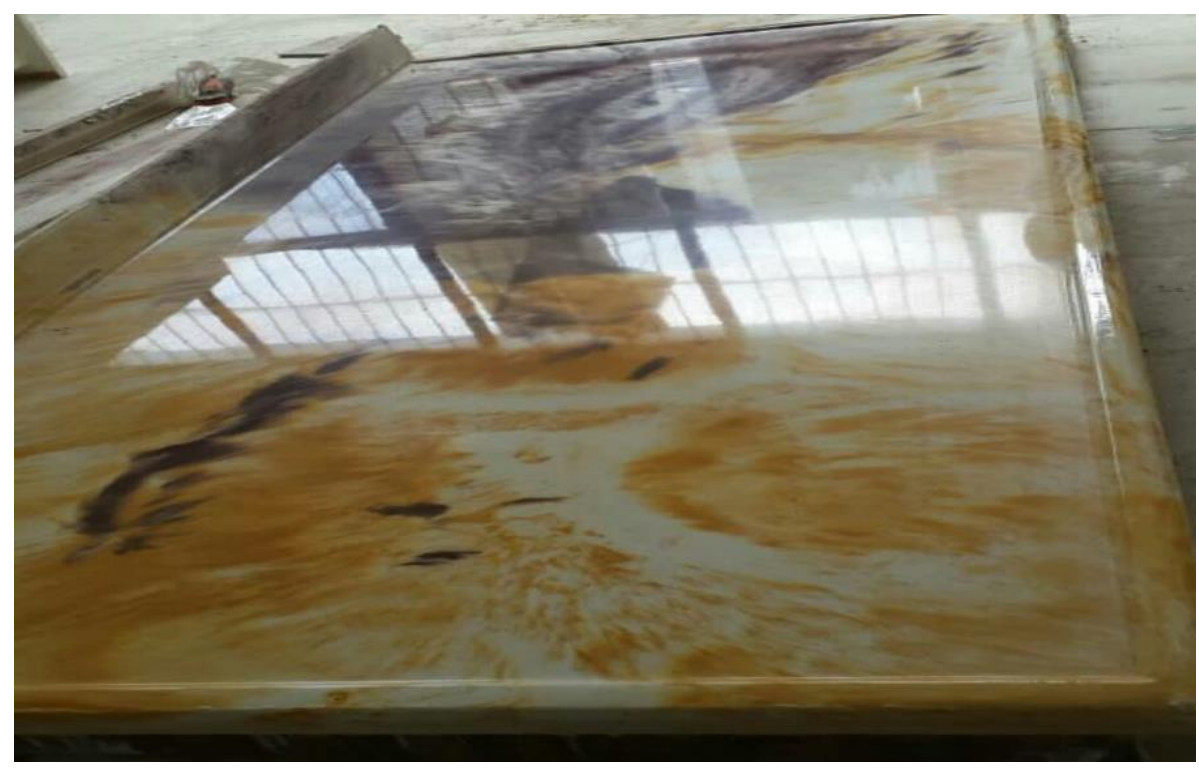

Şekil 8. Ebrulu dökme taş ile üretilen mutfak tezgahı

Şekil 8' de Ebrulu dökme taş ile üretilen mutfak tezgâhı örneği görülmektedir. Tek parça halinde üretilen mutfak tezgahı $150 \mathrm{~cm}$ boyunda ve $65 \mathrm{~cm}$ enindedir. Doğal taş kullanılarak tek parça mutfak tezgâhı üretimi zor iken, yapay taşlarla hiçbir yapıştırma veya ekleme olmadan tek parça olarak üretimi mümkün kılmaktadır. Ebrulu dökme taş mutfak tezgâhının kalınlığı $3 \mathrm{~cm}$ olup, hiç çelik donatı kullanılmadan, polimer ve liflerle güçlendirilerek çekme ve eğilme dayanımı artırılmıştır. 


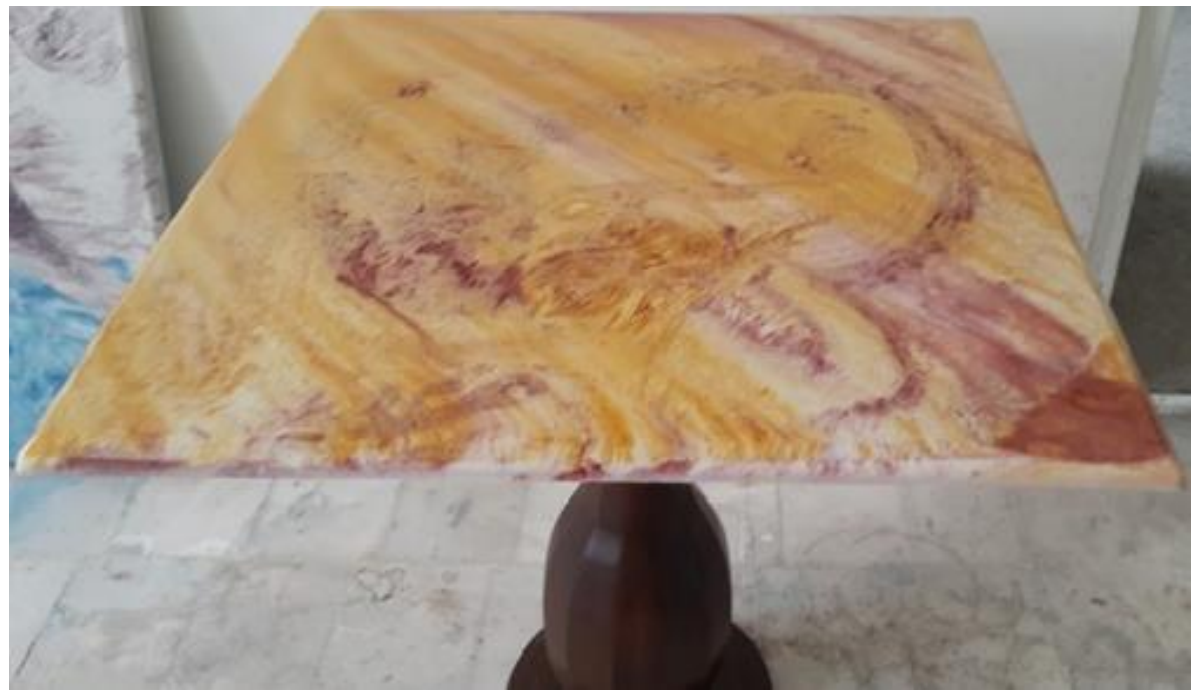

Şekil 9. Ebrulu dökme taş masa örneği

Şekil 9’ da Ebrulu dökme taş ürününün masa olarak kullanımı görülmektedir. Masa olarak kullanılacak olan Ebrulu dökme taş ürünlerinin köşe detayları 45 derece açı olacak şekilde kalıpta pah bırakılarak yapılarak ikinci bir işleme gerek duyulmadan tek parça olarak elde edilmiştir.

\section{Araştırma Bulguları ve Tartışma}

Doğal taşlarda her zaman istenilen renk ve dokuyu bulmak zordur. Doğal taşlara estetik olarak istenen şekil ve ölçüleri vermek makine, teçhizat, işçilik ve zaman gerektirmektedir. Teknolojinin gelişmesi ve artan üretim teknikleri ile dökme taşlar ekonomik olduğu kadar görsel olarak istenen doku ve şekilde kolayca üretmek mümkündür.

Ebru sanatı günümüzde birçok alanda kullanılarak yaşantımızda ki haklı yerini almıştır. İnsanlarda ki farklı renk, işlevsellik, doku ve görsel tema arayışı, sektördeki üreticileri de yönlendirmekte ve sürekli olarak yeniliklere teşvik etmektedir. Yüzey dokusunu ve görsel kaliteyi artırarak müşterisinin beğenisine sunmak isteyen üreticiler, Ebru sanatının muazzam görselliğinden yararlanmaktadırlar. Bu amaçla geliştirilecek olan yeni nesil ev mobilyalarının özgün tasarımları ve renkli görsel dokuları ile kullanıcılar tarafından daha çok arzulanmasını sağlayacaktır.

Bu çalışmamızda Ebru sanatının görsel teması dökme taşların yüzey dokusuna yansıtılarak yeni bir kullanım alanı oluşturulmuştur. Ebrulu dökme taş ürünleri ile sehpa üstü, yemek masası, mutfak tezgâhı, yer ve duvar kaplamaları gibi bir çok alanda kullanılarak, uygulandığı yerlerde görsel kaliteyi yükseltecektir. Ayrıca Ebrulu dökme taş ürünlerinin yüksek mekanik dayanımı hizmet ömrünü artıracaktır.

\section{Sonuç}

Yeni nesil Ebrulu dökme taş ürünlerinin özgün, estetik ve yaratıcı kimliği bulundukları mekânlarda kullanım ve görsel kaliteyi arttıracaktır. Ebrulu dökme taş ürünleri işlevsel, estetik, renk, doku ve algılanabilirlik ölçütleri ile kullanıcısına sınırsız seçenekler sunacaktır.

Görsel algılama ilkeleri doğrultusunda tasarlanacak Ebrulu dökme taş ürünleri işlevsel oldukları kadar birer sanat eseri değerine sahip olacaktır. Ebrulu dökme taş ürünleri ülkemizin kültürel sanatlarından biri olan Ebru sanatını dökme taşların yüzey dokusunda yaşatarak yeni bir kimlik kazandırmış olacaktır.

Ebrulu dökme taş ürünlerinin basınç dayanımı $64 \mathrm{MPa}$ ve eğilme dayanımı 9,6 MPa bulunmuştur. Ebrulu dökme taş ürünlerinin mekanik dayanımları doğal taş hakiki mermerden istenen değerleri sağladığından, doğal taşların kullanıldıkları yerlerde rahatlıkla kullanılacaktır.

Bu çalışmada Ebru sanatın görsel teması kullanılarak mutfak tezgahı, sehpa ve kafe masası üretimi gerçekleştirilmiş̧tir. Ebru sanatı görsel teması ile mutfak tezgâhları, sehpalar, yemek masaları, lavabolar, yer döşemesi ve duvar kaplamaları gibi bütün iç ve dış mekânlar da kullanılabilecek estetik ve dekoratif dökme taş üretimi gerçekleştirilebilinecektir.

Geliştirdiğimiz Ebrulu dökme taş ürünleri ile dökme taş sektörünün gelişimine katkı sağlanacak ve doğal kaynakların daha az tüketilmesini sağlayacaktır. 


\section{Referanslar}

Akman M.S., Yapı Malzemelerinin Tarihsel Gelişimi, TMH - Türkiye Mühendislik Haberleri, s 426, (2003).

Argun İ., "Ebrû Sanat1,” İstanbul İktisat Dergisi, s. 224-225, ss 42-43, (1984).

Arıtan A.S., “Türk Ebru Sanatı ve Bugünkü Durumu,” Selçuk.Üniversitesi Sosyal Bilimler Dergisi, s.8, ss.441, (1999).

Arıtan, A, S, “Türk Ebru Sanatı. Türkler,” Yeni Türkiye Yayınları, Konya, Türkiye, s.12. (2002)

Baradan, B., Felekoğlu, B. “Kendiliğinden Yerleşen Betonların Mekanik Özellikleri”. Beton Kongresi, İzmir, 234-243.(2004).

Felekoğlu B., Yardımcı M.Y.,Baradan B., 'Kendiliğinden Yerleşen Betonların Aşınma ve Donma-Çözülme Direnci,' 5. Ulusal Beton Kongresinde sunuldu, İstanbul, (2003)

Kıran A., "Rengin Psikolojik Etkilerinin İncelenmesi ve Deneysel Psikoloji Yöntemi ile Ülkemiz için 18-25 Yaş Üzerinde Renk Tercihlerinin Saptanması,” Doktora tezi, Y.T.Ü, Ankara, Türkiye, (1986).

Sungur N., "SanatveKimyaBirArada: Ebru,” BilimveTeknikDergisi, s.316, (1994).

T.C. Millî Eğitim Bakanlığı, İnşaat Teknolojisi, Duvara Doğal ve Yapay Taş Kaplama, Erişim: http://megep.meb.gov.tr/, Ankara, (2012).

TS 10449, “Mermer-Kalsiyum karbonat esasl1-Yap1 ve kaplama taşı olarak kullanılan”, TürkStandartlarEnstitüsü,(2009).

TS 12390-4, "Sertleşmiş beton deneyleri - Bölüm 4 : Basınç dayanımı - Deney makinalarının özellikleri”, Türk Standartlar Enstitüsü,(2002).

TS 12390-5, “Sertleşmiş beton deneyleri - Bölüm 5 : Deney numunelerinin eğilme dayanımının tayini”, TürkStandartlarEnstitüsü,(2002).

TS EN 12350-8, “Beton - Taze beton deneyleri - Bölüm 8: Kendiliğinden yerleşen beton - Çökme yayılma deneyi”, Türk Standartlar Enstitüsü,(2011).

Yılmaz, A.D., "Yeni kuşak hiper akışkankanlaştırıcı beton katkıları" TMH - Türkiye Mühendislik Haberleri, Sayı 426, (2003). 